\title{
Role of physical activity in the prevention of falls and their consequences in the elderly
}

\author{
Catarina L. N. Pereira • Peter Vogelaere • \\ Fátima Baptista
}

Received: 30 July 2007 / Accepted: 14 January 2008 /Published online: 23 February 2008

(C) EGREPA 2008

\begin{abstract}
This work aims to provide an inventory of the risk factors and consequences of falling in the elderly, namely fractures, and to identify strategies to prevent falls and minimise their effects. Falls in elderly people are a major cause of injuries, leading to a general fear of falling, poorer quality of life and even death. The increase in life expectancy brought by developments in the medical and health sciences has not always brought enhanced quality of life. More elderly people live with reduced functional capacities resulting in a higher prevalence of falls and associated problems for themselves and for society. Risk factors for falling, commonly resulting from normal aging processes, have already been identified through multiple studies. Exercise may play an important role in fall prevention and their consequences. Although, effective strategies are usually multi-disciplinary and focus simultaneously on several risk factors. However, only large-scale prevention programmes can have significant effective social impact. To minimise occurrence and consequences of falls, policies to systematically implement prevention programmes should be established.
\end{abstract}

C. L. N. Pereira $(\bowtie) \cdot$ P. Vogelaere

Department of Health and Well Being,

University of Évora,

Pavilhão Gimnodesportivo,

Prolongamento da Rua de Monsaraz, 14,

7000 Évora, Portugal

e-mail: clnp@uevora.pt

P. Vogelaere

e-mail: pvogelaere@uevora.pt

F. Baptista

Exercise and Health Laboratory,

Faculty of Human Movement,

Technical University of Lisbon,

Estrada da Costa,

1495-688 Cruz Quebrada, Portugal

e-mail: fbaptista@fmh.utl.pt
Keywords Falls · Risk factors for falling · Elderly · Fractures $\cdot$ Physical activity

\section{Problems of falls}

Falls are a major health problem among the elderly. Thirty percent of people aged 65 and older living in community fall at least once a year [127], and this rate increases with age [108]. As life expectancy increases, there is a higher number of less healthy and less fit elderly people living longer with their infirmities [46, 89, 107]. Consequently, the risk of falls and their consequences is now greater than before [78, 129], as is illustrated by statistics from Finland [75].

Falls are the major cause of death related to mechanical injuries in the elderly, and the mortality rate increases when the individual fall rate increases [41, 45, 112]. According to Rubenstein et al. [119], about $4 \%$ of falls result in fractures and about $11 \%$ result in other serious injuries such as head trauma, soft tissue injuries and severe lacerations. Those who survive falling commonly restrict their activities due to soft tissue injuries and fractures $[15,80]$. Besides injuries and more evident physical consequences, psychological consequences must also be considered: the fear of falling leads to a large percentage of the elderly individuals restricting their activities [22, 48, 130, 137]. Both of these reasons for loss of functionality can result in the "post-fall anxiety syndrome." Less confidence in the ability to walk safely can lead to further functional decline, depression, feelings of helplessness, social isolation $[83,100,119]$ and consequently a loss of quality of life [3]. Inevitably, also, falls and fear of falling are among the major reasons for the institutionalisation of elderly people [41, 49].

According to these factors, falls in the elderly and the resulting injuries have to be considered a social concern, 
not only because of health care costs but also due to psychological problems associated with behavioural modifications, which restrict functional mobility, thus promoting physical dependence and potential changes in lifestyle [135].

\section{Risk factors for falling and fractures}

Falls are defined as any incident in which a person "suddenly and involuntary come to rest upon the ground or a surface lower than the original station" $[62,98]$. Fall consequences, such as fractures, depend fundamentally on three factors:

- Risk factors related to fall occurrences, such as health problems, activity and physical environment

- Risk factors referring to bone strength, namely bone mineral density (BMD), bone structure or the spatial arrangement of the bone trabeculae and bone quality or the mechanical properties of the bone tissue

- Risk factors associated to the impact of the fall, i.e. fall severity, floor material, soft tissue surrounding the impacted bone, etc. $[8,32,51,84,85,106]$
Fractures may occur in any bone of the skeleton. Humeral, fist, pelvis and hip fractures are positively correlated with age and usually result from the combined effects of osteoporosis and the fall proper [15, 76, 77, 95, 101, 105]. Fractures of the vertebrae, also common, are generally associated with osteoporosis [99] and produce a high rate of morbidity and mortality [102]. However, falls may not be the determinant factor of this occurrence in the spine. Table 1 presents the most cited risk factors for falling according to several authors $[2,3,8,9,49,51,64,65,71$, 72, 74, 76, 77, 85, 91, 100, 103, 106, 111, 113, 114, 116, 119, 120].

In the elderly living in communities, the majority of falls occur during usual activities, such as walking or changing position $[129,130]$. They happen mostly at home, so that a "safe home" is fundamental $[90,129]$. Only $5 \%$ of falls are the consequence of clearly hazardous activities, such as climbing on a chair or a ladder or participating in sport activities. About $10 \%$ of falls occur on stairs. It has been shown that going downstairs is more hazardous than climbing [129, 130]. Environmental factors are responsible for most falls, although they are not the main cause for

Table 1 Risk factors for falling

\begin{tabular}{|c|c|c|c|}
\hline \multicolumn{2}{|l|}{ Intrinsic risk factors } & \multicolumn{2}{|c|}{ Extrinsic risk factors } \\
\hline Chronic & Temporary & Activity & Environmental \\
\hline $\begin{array}{l}\text { Age over } 75 \text { years } \\
\text { Incapacity and chronic diseases usually } \\
\text { associated to the degenerative process of } \\
\text { aging: } \\
\text { Degenerations and disturbances of the nervous } \\
\text { and muscular-skeletal system } \\
\text { functions and consequent decrease } \\
\text { of functional capacity: reaction speed, } \\
\text { muscular strength, reflexes, } \\
\text { balance, mobility, gait pattern } \\
\text { and speed } \\
\text { Urinary incontinence } \\
\text { Deficient vision } \\
\text { Vestibular function disturbance } \\
\text { Audition loss } \\
\text { Cognitive function disturbance } \\
\text { Insanity } \\
\text { Depression } \\
\text { Memory loss } \\
\text { Neurological pathologies such as } \\
\text { Parkinson's disease } \\
\text { Secondary effects of medication }\end{array}$ & $\begin{array}{l}\text { Loss of conscience } \\
\text { Medication/drugs/ } \\
\text { alcohol } \\
\text { Other } \\
\text { hallucinogenic } \\
\text { substances }\end{array}$ & $\begin{array}{l}\text { Usual activities } \\
\text { Hazardous } \\
\text { activities }\end{array}$ & $\begin{array}{l}\text { Indoor: } \\
\text { Bad lighting } \\
\text { Slippery floors, loose rugs, } \\
\text { telephone threads, other objects } \\
\text { Ladders } \\
\text { Stairways with steep steps, } \\
\text { without walls and/or handrails } \\
\text { Kitchen with difficult access to } \\
\text { utensils and movable tables } \\
\text { Bathroom without handrails for } \\
\text { tub, shower and toilet and non- } \\
\text { skid mat in tub or shower } \\
\text { Bed too high or too low } \\
\text { Outdoor: } \\
\text { Uneven pavements, streets, paths } \\
\text { Repair works, obstacles } \\
\text { Slippery floors } \\
\text { Rain, snow and ice } \\
\text { Traffic } \\
\text { Public transport } \\
\text { Animals } \\
\text { Footwear }\end{array}$ \\
\hline
\end{tabular}


falling. However, few falls result from unpredictable events [129].

According to Bath and Morgan [13], falls in outdoor and indoor environments present different risk profiles. Risk factors associated with outdoor falls are both intrinsic and extrinsic. Intrinsic risk factors include decreased functional capacities such as reduced strength and/or reduced gait velocity, while extrinsic factors are related to hazardous environments and performances outside habitual activities. Risk factors associated with indoor falls are mainly intrinsic and their occurrence increases when the elderly are housebound, due to poor health, frailty or to the use of high levels of prescribed medications. It is important to note that people falling at home present a higher mortality rate, although the relationship between causality and effect is still unclear. Table 2 provides a review of the risk factors for fractures due to falling $[32,60,65,74,93,94,103,105$, $106,122,134]$.

Bone strength is determined $65-80 \%$ by BMD (quantity of bone mineral per square or cubic centimetre) and 20 $35 \%$ by bone structure (spatial arrangement of the bone trabeculae), as well as by bone quality (the material

Table 2 Risk factors for fractures due to falling

\section{Risk factors}

Risk factors inherent to the individual:

Age (specially over 75 years)

Female (vs. male)

Family history of fractures due to osteoporosis (maternal hip fracture)

Recurrent falls in previous year

Previous fracture caused by a low energy impact

Osteopenia, osteoporosis and associated disorders

Low body weight (body mass index $<19 \mathrm{~kg} / \mathrm{m}^{2}$ )

Bone structure: geometry and lenght

Corticosteroids treatments

Hormonal factors

Behaviour risk factors:

Nutritional factors

Low consumption of calcium $(<700 \mathrm{mg} / \mathrm{d})$

Vitamin D deficit (low exposition to sun light)

Physical inactivity

Tobacco

Alcohol

Factors that potentiate falls impact:

Height (the taller the person the greater the impact)

Decreased muscular and fat mass

Lateral falls

Point of impact on the bone (for instance the femoral neck)

Loss of defence reflexes

Floor surface

No use of artificial shock absorber (reduction of the occurrence of fractures by $40 \%$ ) properties of bone tissue) [71, 106]. BMD, in turn, is determined by genetic and hormonal factors, body composition, nutrition, physical activity, chronic diseases and the use of medication [16, 29, 35, 39, 71, 106, 111, 120].

Evaluation of BMD may be performed by dual-energy $\mathrm{X}$-ray absorptiometry [25]. Osteoporosis is diagnosed in post-menopausal women and in men age 50 and older if BMD expressed as T-score is -2.5 or less at the lumbar spine, total hip of femoral neck [66]. The T-score indicates how many standard deviations (SDs), above or below the average value, the result in question actually lies. The reference standard from which the T-score is calculated is the BMD of the young adult age 20-29 years. A T-score between -1.0 and -2.5 SDs indicates low bone density or mass, also usually referred to as osteopenia. Contrary to osteoporosis, people with low bone mass are not necessarily at high fracture risk $[21,74]$.

The risk of falling and fracture is related to the number of existing risk factors and is potentiated by the interaction and cumulative effects of multiple risks [32, 36, 128, 130]. However, many of those risk factors can be avoided [128, 134] or reduced when some contributing factors are modified by intervention programmes [114, 122, 130], particularly, when these programmes are multi-factorial $[37,90,115]$.

\section{Prevention strategies for falls and fractures}

Most elderly people are not aware of their predisposition to fall nor identify their inherent risk factors, and thus they cannot express their limitations to a physicians or other healthcare personnel. Consequently, as prevention is often overlooked, the risk becomes evident only after a lesion or incapacity due to a fall $[19,28]$.

The correct diagnosis of this reality is fundamental. The use of proficient instruments to recognize the predisposed risk factors responsible for the occurrence of serious lesions and the evaluation of behavioural risk factors allow the identification of populations and individuals at risk [44, 98, $104,115,123]$. This knowledge leads to the setting up and implementation of efficient intervention programmesfocussed on the existing risk factors and providing answers to the needs of the individual or specific population groups (age, gender, functional competence, clinical condition, type of performed activities, etc.) [62, 98, 104, 127].

Physical exercise programmes

Independently of individual differences, fragilities or pathologies, light- to moderate-intensity exercise programmes revealed to be effective in the prevention of falls and their consequences. Tai-chi, step, strength, 
agility, stretching and multi-modal training or adhesion to specific programmes of exercise directed to prevent falls have reduced fall events, falls injuries and also fear of falling [2, 11, 20, 26, 27, 34, 38, 42, 86, 91, 116, 127]. Exercise may prevent falls and their consequences either in healthy old people or in elderly people with medical conditions like osteoporosis, Parkinson, diabetes, physical or visual impairment and even after a stroke $[6,10,14,38$, $61,82,99,110]$.

Maintenance or recovery of the elderly physical functionality through such exercise programmes $[1,27,33,60,73$, $86,87,133]$, besides decreasing fall rate and its consequences $[18,47,92,96]$, contribute to improving the quality of life [109]. To be effective, these programmes, performed on a daily basis, have to be focussed on functional capacities, such as coordination, agility, balance, mobility, muscular strength and flexibility [12, 50, 63, 113-115, 121, 123, 135]. They should also include multi-sensorial training $[67,116]$, as well as exercises like walking, stepping up- or downstairs, and carrying objects [2, 87, 116]. Training programmes aiming to improve weight-bearing bones and muscles can also improve functionality, reduce fall severity and even lower the mortality rate $[24,53,69,81,124]$.

Regarding bone health, increase of bone strength during pre-puberty and adolescent years is fundamental for the prevention of osteoporosis and related fractures in older people [58, 72]. Mechanical loading such as high-impact and resistance exercise enhances peak bone mass during growing years and prevents bone loss during aging throughout bone formation stimulation [76, 81, 97, 124]. Recently, the use of high-frequency vibratory platforms has showed significant increase of bone mineral at the hip level, associated with an improvement of balance [57]. These exercise programmes need to be long-term projects, as any interruption will induce a reversibility of the benefits in health and function, especially at the muscle and skeleton levels $[18,23,40,81]$. Moreover, decreases in physical performance associated with the lack of activity in the elderly are associated with dependence and the incapacity to perform daily tasks [52].

As it has been exposed, studies suggest that a moderate level of physical activity can reduce the risk of falls and prevent their consequences like fractures and other injuries $[17,55]$. Even light or vigorous exercise can produce health benefits $[18,88]$. However, there are no guidelines for exercise prescription, namely the optimal intensity and amount of activity necessary to prevent falls. "Staying active-staying safe" [4] does not mean the greater the amount of physical activity the better. In fact, several authors exposed that either inactivity or excessive physical activity may conduce to the occurrence of fall events, particularly when heavy tasks are involved $[30,54]$. The higher rate of falls associated with inactivity seems to be due to the usual function decline of sedentary elderly people $[38,59$, 97, 125]. The higher rate of falls associated with excessive physical activity may be due to the fact that people fall when they are moving, especially performing heavy tasks in a noncontrolled environment, and then the probability of the occurrence of an accidental fall is amplified [7].

\section{Multi-disciplinary programmes}

In addition to the evidence that interventions centred on physical exercise are beneficial, literature also reveals the importance of multi-faceted intervention in the prevention of falls and consequent fractures [43, 62, 90, 127]. Besides exercise, prevention programmes must include strategies to improve cognition, especially the capacity to perform dualtask walking to ensure appropriate nutrition, particularly ingestion of calcium and vitamin $\mathrm{D}$, and when appropriate to change prescription of drugs with possible negative secondary effects. Home assessment performed by specialised personnel and continuous counselling about safety conditions in the house and its accesses are also recommended. Such work has to be performed in close consultation with the subjects in their local environment $[5$, $9,43,64,68,70,117,136]$.

It is not yet clear which is the most valuable component in a multi-factorial intervention programme. However, prevention programmes have already been implemented and are providing effective results $[31,56,86,103,114$, 126, 132]. Despite a universally successful prevention strategy is not applicable because falling and consequent fractures depend on each faller [62], preventive measures need to be implemented systematically and performed on a large scale $[79,118,131]$.

\section{Conclusion}

For the elderly, falls and fear of falling induce loss of autonomy and reduce the quality of life. Aside from the financial costs, falls cause both physical and psychological suffering. Risk factors for falling are multiple and well documented, as are their consequences. Most risk factors are due to normal aging processes and can be attenuated or eliminated. Others are intractable, which means that the elderly must simply learn to live with them.

Physical exercise should be part of a multi-disciplinary strategy to prevent falls and their consequences to maximise intervention benefits. Although risk factors for falling have been accurately defined and some management strategies studied and, in some cases, implemented, most approaches lack continuity. What remain are the policies to raise awareness and promote the widespread, systematic implementation of comprehensive prevention programmes. 


\section{References}

1. Ahacic K, Parker M, Thorslund M (2003) Mobility limitations 1974-1991: period changes explaining improvement in the population. Soc Sci Med 57:2411-2422

2. Alexander NB, Goldberg A (2006) Clinical gait and stepping performance measures in older adults. Eur Rev Aging Phys Act 3:20-28

3. Arfken CL, Lach HW, Birge SJ, Miller JP (1994) The prevalence and correlates of fear of falling in elderly persons living in the community. Am J Public Health 84:565-570

4. Armstrong M, Bates A, Castell S, Krolik P (2002) Staying activestaying safe: development of a physical activity and falls prevention resource for older people who dwell in the community. N S W Public Health Bull 13:13-14

5. Asakawa Y, Takahashi R, Endo F (2006) Fall prevention strategy for elderly women wishing to attend community fall prevention programs. Nippon Ronen Igakkai Zasshi 43:117-121

6. Ashburn A, Fazakarley L, Ballinger C, Pickering R, McLellan LD, Fitton C (2007) A randomised controlled trial of a home based exercise programme to reduce the risk of falling among people with Parkinson's disease. J Neurol Neurosurg Psychiatry 78:678-684

7. Association of Emergency Medical Technicians ACoS (2003) Injury prevention. PHTLS, basic and advanced prehospital trauma life support. Mosby, St. Louis, pp 10-25

8. Augat P, Schorlemmer S (2006) The role of cortical bone and its microstructure in bone strength. Age Ageing 35(Suppl 2):ii27-ii31

9. Bae JM, Koo HW, Jung KO, Park BJ (2002) A cohort study on the association between psychotropics and hip fracture in Korean elderly women. J Korean Med Sci 17:65-70

10. Bast BA, Greenwald BD (2007) Preventing hip fracture after stroke. Top Stroke Rehabil 14:67-79

11. Bateni H, Maki BE (2005) Assistive devices for balance and mobility: benefits, demands, and adverse consequences. Arch Phys Med Rehabil 86:134-145

12. Bateni H, Zecevic A, McIlroy WE, Maki BE (2004) Resolving conflicts in task demands during balance recovery: does holding an object inhibit compensatory grasping? Exp Brain Res 157:49-58

13. Bath P, Morgan K (1999) Differential risk profiles for indoor and outdoor falls in older people living in home in Nottingham, UK. Eur J Epidemiol 15:65-73

14. Beaudreuil J (2006) Nonpharmacological treatments for osteoporosis. Ann Readapt Med Phys 49:581-588

15. Bell A, Talbot-Stern J, Hennessy A (2000) Characteristics and outcomes of older patients presenting to the emergency department after a fall: a retrospective analysis. Med J Aust 173:179-182

16. Bell N (2003) RANK ligand and regulation of skeletal remodelling. J Clin Invest 111:1120-1122

17. Borer KT (2005) Physical activity in the prevention and amelioration of osteoporosis in women: interaction of mechanical, hormonal and dietary factors. Sports Med 35:779-830

18. Boyle PA, Buchman AS, Wilson RS, Bienias JL, Bennett DA (2007) Physical activity is associated with incident disability in community-based older persons. J Am Geriatr Soc 55:195-201

19. Braun B (1998) Knowledge and perception of fall-related risk factors and fall-reduction techniques among communitydwelling elderly individuals. Phys Ther 78:1262-1276

20. Brouwer BJ, Walker C, Rydahl SJ, Culham EG (2003) Reducing fear of falling in seniors through education and activity programs: a randomized trial. J Am Geriatr Soc 51:829-834

21. Brown J, Josse R (2002) 2002 clinical practice guidelines for the diagnosis and management of osteoporosis in Canada. CMAJ 12: S1-S34
22. Bruce DG, Devine A, Prince RL (2002) Recreational physical activity levels in healthy older women: the importance of fear of falling. J Am Geriatr Soc 50:84-89

23. Buchman AS, Boyle PA, Wilson RS, Bienias JL, Bennett DA (2007) Physical activity and motor decline in older persons. Muscle Nerve 35:354-362

24. Buchman AS, Wilson RS, Boyle PA, Bienias JL, Bennett DA (2007) Change in motor function and risk of mortality in older persons. J Am Geriatr Soc 55:11-19

25. Cadarette S, Jaglal S, Kreiger N, McIsaac W, Darlington G, Tu J (2000) Development and validation of the Osteoporosis Risk Assessment Instrument to facilitate selection of women for bone densitometry. CMAJ 162:1289-1294

26. Cao ZB, Maeda A, Shima N, Kurata H, Nishizono H (2007) The effect of a 12-week combined exercise intervention program on physical performance and gait kinematics in communitydwelling elderly women. J Physiol Anthropol 26:325-332

27. Carter ND, Khan KM, McKay HA, Petit MA, Waterman C, Heinonen A, Janssen PA, Donaldson MG, Mallinson A, Riddell L, Kruse K, Prior JC, Flicker L (2002) Community-based exercise program reduces risk factors for falls in 65- to 75year-old women with osteoporosis: randomised controlled trial. CMAJ 167:997-1004

28. Cavanillas A, Ruiz F, Alonso C, Garcia M, Vargas R (1999) Factores de riesgo de caídas en una población institucionalizada. Estudio de cohortes prospectivo. Med Clin 112:10-15

29. Center J, Nguyen T, Sambrook P, Eisman J- (1999) Hormonal and biochemical parameters in the determination of osteoporosis in elderly men. J Clin Endocrinol 84:3626-3635

30. Chan BK, Marshall LM, Winters KM, Faulkner KA, Schwartz AV, Orwoll ES (2007) Incident fall risk and physical activity and physical performance among older men: the Osteoporotic Fractures in Men Study. Am J Epidemiol 165:696-703

31. Chang J, Morton S, Rubenstein L (2004) Interventions for the prevention of falls in older adults: systematic review and metaanalysis of randomised clinical trials. BMJ 326:680-683

32. Cooper C, Barker D (1995) Risk factors for hip fracture. N Engl J Med 332:814-815

33. Cornillon E, Blanchon $\mathrm{M}$, Ramboatsisetraina $\mathrm{P}$, Braize $\mathrm{C}$, Beauchet V, Dubost V, Banc P, Gonthier R (2002) Impact d'un programme de prévention multidisciplinaire de la chute chez le sujet âgé autonome vivant à domicile, avec analyse avant-après des performances physiques. Ann Readapt Med Phys 45:493-504

34. Cumming RG (2002) Intervention strategies and risk-factor modification for falls prevention. A review of recent intervention studies. Clin Geriatr Med 18:175-189

35. Cummings S, Black D, Thompson D, Applegate W, BarrettConnor E, Musliner T, Palermo L, Prineas R, Rubin S, Scott J, Vogt T, Wallace R, Yates J, LaCroix A (1998) Effect of alendronate on risk of fracture in women with low bone density but without vertebral fractures. JAMA 280:2077-2082

36. Cummings S, Nevitt M, Browner W, Stone K, Fox K, Ensrud K, Cauley J, Black D, Vogt T (1995) Risk factors for hip fracture in white women. Study of Osteoporotic Fractures Research Group. N Engl J Med 332:767-774

37. Day L, Fildes B, Gordon I, Fitzharris M, Flamer H, Lord S (2002) Randomised factorial trial of falls prevention among older people living in their own homes. BMJ 325:1-6

38. Delbaere K, Bourgois J, Van Den Noortgate N, Vanderstraeten G, Willems T, Cambier D (2006) A home-based multidimensional exercise program reduced physical impairment and fear of falling. Acta Clin Belg 61:340-350

39. Dempster P, Aitkens S (1995) A new air displacement method for the determination of human body composition. Med Sci Sports Exerc 27:1692-1697 
40. Dipietro L (2001) Physical activity in aging: changes in patterns and their relationship to health and function. J Gerontol 56A:13-22

41. Donald I, Bulpitt C (1999) The prognosis of falls in elderly people living at home. Age Ageing 28:121-125

42. Donat H, Ozcan A (2007) Comparison of the effectiveness of two programmes on older adults at risk of falling: unsupervised home exercise and supervised group exercise. Clin Rehabil 21:273-283

43. Feder G, Cryer C, Donovan S, Carter Y (2000) Guidelines for the prevention of falls in people over 65 . The Guidelines' Development Group. BMJ 321:1007-1011

44. Ferrucci L, Bandinelli S, Cavazzini C, Lauretani F, Corsi A, Bartali B, Cherubini A, Launer L, Guralnik JM (2004) Neurological examination findings to predict limitations in mobility and falls in older persons without a history of neurological disease. Am J Med 116:807-815

45. Fried LF, Biggs ML, Shlipak MG, Seliger S, Kestenbaum B, Stehman-Breen C, Sarnak M, Siscovick D, Harris T, Cauley J, Newman AB, Robbins J (2007) Association of kidney function with incident hip fracture in older adults. J Am Soc Nephrol 18:282-286

46. Friedenberg R (2002) Longevity. Radiology 223:597-601

47. Fuzhong L, Fisher KJ, Harmer P, MacAuley E (2005) Falls self-efficacy as a mediator of fear of falling in an exercise intervention for older adults. J Gerontol B Psychol Sci Soc Sci 60:P34-P40

48. Fuzhong L, Fisher KJ, Harmer P, MacAuley E, Wilson NL (2003) Fear of falling in elderly persons: association with falls, functional ability and quality of life. J Gerontol B Psychol Sci Soc Sci 58B:P283-P290

49. Fuzhong L, McAuley E, Fisher KJ, Harmer P, Chaumeton N, Wilson NL (2002) Self-efficacy as a mediator between fear of falling and functional ability in the elderly. J Aging Health $14: 452-466$

50. Galvão A, Taaffe D (2005) Resistance exercise dosage in older adults: single- versus multiset effects on physical performance and body composition. J Am Geriatr Soc 53:2090-2097

51. Geraets WG, Van der Stelt PF, Lips P, Van Ginkel FC (1998) The radiographic trabecular pattern of hips in patients with hip fractures and in elderly control subjects. Bone 22:165-173

52. Gill T, Williams C, Leon C, Tinetti M (1997) The role of change in physical performance in determining risk for dependence in activities of daily living among nondisabled community-living elderly persons. J Clin Epidemiol 50:765-772

53. Goodpaster BH, Park SW, Harris TB, Kritchevsky SB, Nevitt M, Schwartz AV, Simonsick EM, Tylavsky FA, Visser M, Newman AB (2006) The loss of skeletal muscle strength, mass, and quality in older adults: the health, aging and body composition study. J Gerontol A Biol Sci Med Sci 61:1059-1064

54. Gregg EW, Cauley JA, Seeley DG, Ensrud KE, Bauer DC (1998) Physical activity and osteoporotic fracture risk in older women. Study of Osteoporotic Fractures Research Group. Ann Intern Med 129:81-88

55. Gregg EW, Pereira MA, Caspersen CJ (2000) Physical activity, falls, and fractures among older adults: a review of the epidemiologic evidence. J Am Geriatr Soc 48:883-893

56. Grenier-Sennelier C, Lombard I, Jeny-Loeper C, Maillet-Gouret M, Minvielle E (2002) Designing adverse event prevention programs using quality management methods: the case of falls in hospital. Int J Qual Health Care 14:419-426

57. Gusi N, Raimundo A, Leal A (2006) Low-frequency vibratory exercise reduces the risk of bone fracture more than walking: a randomized controlled trial. BMC Musculoskelet Disord 7:92

58. Haapasalo H, Kannus P, Sievanen H (1996) Development of mass density and estimated mechanical characteristics of bones in Caucasian females. J Bone Miner Res 11:1751-1760
59. Hauer K, Becker C, Lindemann U, Beyer N (2006) Effectiveness of physical training on motor performance and fall prevention in cognitively impaired older persons: a systematic review. Am J Phys Med Rehabil 85:847-857

60. Herala M, Kivela SL, Honkanen R, Koski K, Laippala P, Luukinen H (2002) Recent decline in heavy outdoor work activity predicts occurrence of fractures among the homedwelling elderly. Osteoporos Int 13:42-47

61. Hofbauer LC, Brueck CC, Singh SK, Dobnig H (2007) Osteoporosis in patients with diabetes mellitus. J Bone Miner Res 22:1317-1328

62. Hogan DB, MacDonald FA, Betts J, Bricker S, Ebly EM, Delarue B, Fung TS, Harbidge C, Hunter M, Maxwell CJ, Metcalf B (2001) A randomized controlled trial of a communitybased consultation service to prevent falls. CMAJ 165:537-543

63. Holland G, Tanaka K, Shigematsu R, Nakagaichi M (2002) Flexibility and physical functions of older adults: a review. J Aging Phys Act 10:169-206

64. Hollman JH, Kovash FM, Kubik JJ, Linbo RA (2007) Agerelated differences in spatiotemporal markers of gait stability during dual task walking. Gait Posture 26:113-119

65. Hundrup YA, Ekholm O, Hoidrup S, Davidsen M, Obel EB (2005) Risk factors for hip fracture and a possible effect modification by hormone replacement therapy. The Danish Nurse Cohort Study. Eur J Epidemiol 20:871-877

66. International Society for Clinical Densitometry (2007) Official positions of the International Society for Clinical Densitometry. http://www.ISCD.org. Accessed 25 July

67. Islam M, Nasu E, Rogers M, Koizumi D, Rogers N, Takeshima N (2004) Effects of combined sensory and muscular training on balance in Japanese older adults. Prev Med 39:1148-1155

68. Jackson R, Fantom J (2002) A pilot scheme for an integrated falls prevention service. Orthop Nurs 6:204-210

69. Janssen I, Baumgartner RN, Ross R, Rosenberg IH, Roubenoff R (2004) Skeletal muscle cutpoints associated with elevated physical disability risk in older men and women. Am J Epidemiol 159:413-421

70. Jensen J, Nyberg L, Gustafson Y, Lundin-Olsson L (2003) Fall and injury prevention in residential care-effects in residents with higher and lower levels of cognition. J Am Geriatr Soc 51:627-635

71. Johnston CC Jr., Slemenda CW (1993) Determinants of peak bone mass. Osteoporos Int 3(Suppl 1):54-55

72. Johnston CC Jr., Slemenda CW (1994) Peak bone mass, bone loss and risk of fracture. Osteoporos Int 4(Suppl 1):43-45

73. Jones J, Rikli R (2000) The application of Fullerton's Functional Fitness Test for older adults in a group setting. Sci Sports 15:194-197

74. Kanis J (2002) Osteoporosis III: diagnostic of osteoporosis and assessment of fracture risk. Lancet 359:1929-1936

75. Kannus P, Niemi S, Palvanem M, Parkkari J (2005) Rising incidence of fall-induced injuries among elderly adults. J Public Health 13:212-215

76. Kannus P, Palvanem M, Niemi S, Parkkari J, Jarvinem M (2000) Epidemiology of osteoporotic pelvic fractures in elderly people in Finland: sharp increase in 1970-1997 and alarming projections for the new millennium. Osteoporos Int 11:443-448

77. Kannus P, Palvanem M, Niemi S, Parkkari J, Jarvinem M (2002) Increasing number and incidence of low-trauma ankle factures in elderly people: Finnish statistics during 1970-2000 and projections for the future. Bone 31:430-433

78. Kannus P, Parkkari J, Koskimen S, Niemi S, Palvanem M, Jarvinem M, Vuori I (1999) Fall-induced injuries and deaths among older adults. JAMA 281:1895-1899

79. Kannus P, Sievanen H, Palvanen M, Jarvinen T, Parkkari J (2005) Prevention of falls and consequent injuries in elderly people. Lancet 366:1885-1893 
80. Kempen G, Ormel J, Scaf-Klomp W, Sonderen E, Ranchor A, Sanderman R (2003) The role of perceived control in the process of older peoples recovery of physical functions after fall-related injuries: a prospective study. J Gerontol 58B:P35-P41

81. Kontulainen S, Heinonen A, Kannus P, Pasanen M, Sievanen H, Vuori I (2004) Former exercisers of an 18-month intervention display residual aBMD benefits compared with control women 3.5 years post-intervention: a follow-up of a randomised controlled high-impact trial. Osteoporos Int 15:248-251

82. La Grow SJ, Robertson MC, Campbell AJ, Clarke GA, Kerse NM (2006) Reducing hazard related falls in people 75 years and older with significant visual impairment: how did a successful program work? Inj Prev 12:296-301

83. Lenze EJ, Munin MC, Skidmore ER, Amanda Dew M, Rogers JC, Whyte EM, Quear T, Begley A, Reynolds CF 3rd (2007) Onset of depression in elderly persons after hip fracture: implications for prevention and early intervention of late-life depression. J Am Geriatr Soc 55:81-86

84. Lips P (1996) Prevention of hip fractures: drug therapy. Bone 18:159S-163S

85. Lips P, Obrant KJ (1991) The pathogenesis and treatment of hip fractures. Osteoporos Int 1:218-231

86. Liu-Ambrose T, Kan K, Eng J, Gillies G, Lord R, McKay H (2005) The beneficial effects of group-based exercises on fall risk profile and physical activity persist 1 year postintervention in older women with low bone mass: follow-up after withdrawal of exercise. J Am Geriatr Soc 53:1767-1773

87. Lord SR, Castell S, Corcoran J, Dayhew J, Matters B, Shan A, Williams P (2003) The effect of group exercise on physical functioning and falls in frail older people living in retirement villages: a randomised, controlled trial. J Am Geriatr Soc 51:1685-1692

88. Lord SR, Castell S, Corcoran J, Dayhew J, Matters B, Shan A, Williams P (2003) The effect of group exercise on physical functioning and falls in frail older people living in retirement villages: a randomized, controlled trial. J Am Geriatr Soc 51:1685-1692

89. Lubitz J, Cai L, Kramarow E, Lentzner H (2003) Health, life expectancy and health care spending among the elderly. N Engl $\mathrm{J}$ Med 349:1048-1055

90. Lundebjerg N (2001) Guideline for the prevention of falls in older persons. J Am Geriatr Soc 49:664-672

91. Madureira MM, Takayama L, Gallinaro AL, Caparbo VF, Costa RA, Pereira RM (2007) Balance training program is highly effective in improving functional status and reducing the risk of falls in elderly women with osteoporosis: a randomized controlled trial. Osteoporos Int 18:419-425

92. Mancini C, Williamson D, Binkin N, Michieletto F, De Giacomi GV (2005) Epidemiology of falls among the elderly. Ig Sanita Pubbl 61:117-132

93. Marks R, Allegrante J, MacKenzie C, Lane J (2003) Hip fractures among the elderly: causes, consequences and control. Ageing Res Rev 2:57-93

94. Marshall D, Johnell O, Wedel H (1996) Meta-analysis of how well measures of bone mineral density predict occurrence of osteoporotic fractures. BMJ 312:1254-1259

95. Melton L, Riggs B (1985) Risk factors for injury after a fall. Clin Geriatr Med 1:525-539

96. Nelson ME, Rejeski WJ, Blair SN, Duncan PW, Judge JO, King AC, Macera CA, Castaneda-Sceppa C (2007) Physical activity and public health in older adults: recommendation from the American College of Sports Medicine and the American Heart Association. Circulation 116:1094-1105

97. Neville C, Murray L, Boreham C, Gallagher A, Twisk J, Robson P, Savage J, Kemper H, Ralston S, Smith G (2002) Relationship between physical activity and bone mineral status in young adults: the Northern Ireland Young Hearts Project. Bone 30:792-798
98. Oliver D, Britton M, Seed P, Martin F, Hopper A (1997) Development and evaluation of evidence based risk assessment tool (stratify) to predict which elderly inpatients will fall: casecontrol and cohort studies. BMJ 315:1049-1053

99. O'Neill TW, Lunt M, Silman AJ, Felsenberg D, Benevolenskaya LI, Bhalla AK, Cannata JB, Cooper C, Crabtree N, Dequeker J, Hoszowski K, Jajic I, Kanis JA, Kragl G, Lopes Vaz A, Lorenc R, Lyritis G, Masaryk P, Miazgowski T, Parisi G, Pols HAP, Poor G, Reid DM, Scheidt-Nave C, Stepan J, Todd C, Weber K, Woolf AD, Reeve J (2002) The relationship between bone density and incident vertebral fracture in men and women. $\mathrm{J}$ Bone Miner Res 17:2214-2221

100. Oude Voshaar RC, Banerjee S, Horan M, Baldwin R, Pendleton N, Proctor R, Tarrier N, Woodward Y, Burns A (2006) Fear of falling more important than pain and depression for functional recovery after surgery for hip fracture in older people. Psychol Med 36:1635-1645

101. Palvanem M, Kannus P, Parkkari J, Pitkajarvi T, Pasanen M, Vuori I, Jarvinem M (2000) The injury mechanisms of osteoporotic upper extremity fractures among older adults: a controlled study of 287 consecutive patients and their 108 controls. Osteoporos Int 11:822-831

102. Peel NM, Kassulke DJ, McClure RJ (2002) Population based study of hospitalised fall related injuries in older people. Inj Prev 8:280-283

103. Peel NM, McClure RJ, Hendrikz JK (2006) Health-protective behaviours and risk of fall-related hip fractures: a populationbased case-control study. Age Ageing 35:491-497

104. Perell KL, Nelson A, Goldman RL, Luther SL, Prieto-Lewis N, Rubenstein LZ (2001) Fall risk assessment measures: an analytic review. J Gerontol A Biol Sci Med Sci 56:M761-766

105. Pickett W, Hartling L, Brison RJ (1997) A population-based study of hospitalised injuries in Kingston, Ontario, identified via the Canadian Hospitals Injury Reporting and Prevention Program. Chronic Dis Can 18:61-69

106. Pluijm S (2001) Predictors and consequences of falls and fractures in the elderly. Vrije Universiteit, Amsterdam

107. Portugal INE (2005) Dia internacional do idoso. Destaque Informação à Comunicação Social:1-6

108. Prudham D, Evans JG (1981) Factors associated with falls in the elderly: a community study. Age Ageing 10:141-146

109. Rejeski W, Mihalko S (2001) Physical activity and quality of life in older adults. J Gerontol 56A:23-35

110. Richerson S, Rosendale K (2007) Does Tai Chi improve plantar sensory ability? A pilot study. Diabetes Technol Ther 9:276-286

111. Riggs BL, Khosla S, Melton LJ 3rd (2002) Sex steroids and the construction and conservation of the adult skeleton. Endocr Rev 23:279-302

112. Robbins JA, Biggs ML, Cauley J (2006) Adjusted mortality after hip fracture: from the Cardiovascular Health Study. J Am Geriatr Soc 54:1885-1891

113. Rogers ME, Fernandez JE, Bohlken RM (2001) Training to reduce postural sway and increase functional reach in the elderly. J Occup Rehabil 11:291-298

114. Rogers ME, Rogers NL, Chaparro BS, Stumpfhauser L, Halcomb CG (2003) Effects of modular course training on mobility in older adults aged 79-90 years. Disabil Rehabil 25:213-217

115. Rogers ME, Rogers NL, Takeshima N, Islam MM (2003) Methods to assess and improve the physical parameters associated with fall risk in older adults. Prev Med 36:255-264

116. Rose D (2002) Promoting functional independence among "at risk" and physically frail older adults through community-based fall-risk-reduction programs. J Aging Phys Act 10:207-225

117. Rossouw J (2002) Risks and benefits of estrogen plus progestin in healthy postmenopausal women: principal results from the Women's Health Initiative Randomised Controlled Trial. JAMA 288:321-333 
118. Rubenstein LZ (2006) Falls in older people: epidemiology, risk factors and strategies for prevention. Age Ageing 35(Suppl 2): ii37-ii41

119. Rubenstein LZ, Josephson KR, Robbins AS (1994) Falls in the nursing home. Ann Intern Med 121:442-451

120. Sato Y, Honda Y, Kunoh K, Oizumi K (1997) Long-term oral anticoagulation reduces bone mass in patients with previous hemispheric infarction and nonrheumatic atrial fibrillation. Stroke 28:2390-2394

121. Sinaki M, Itoi E, Wahner H, Wollan P, Gelzcer R, Mullan B, Collins D, Hodgson S (2002) Stronger back muscles reduce the incidence of vertebral fractures: a prospective 10 years follow-up of postmenopausal women. Bone 30:836-841

122. Slemenda C (1997) Prevention of hip fractures - risk factor modification. Am J Med 103:65S-71S

123. Stel VS, Smit JH, Pluijm SM, Lips P (2003) Balance and mobility performance as treatable risk factors for recurrent falling in older persons. J Clin Epidemiol 56:659-668

124. Stewart K, Bacher A, Hees P, Tayback M, Ouyang P, Beur S (2005) Exercise effects on bone mineral density. Relationships to change in fitness and fatness. Am J Prev Med 28:453-460

125. Suzuki T, Kim H, Yoshida H, Ishizaki T (2004) Randomized controlled trial of exercise intervention for the prevention of falls in community-dwelling elderly Japanese women. J Bone Miner Metab 22:602-611

126. Tinetti M (2003) Preventing falls in elderly persons. N Engl J Med 348:42-49

127. Tinetti M, Baker D, MacAvay G, Claus E, Garrett P, Gottschalk M, Koch M, Trainor K, Horwitz R (1994) A multifactorial intervention to reduce the risk of falling among elderly people living in the community. N Engl J Med 331:821-827
128. Tinetti M, Doucette H, Claus E (1995) The contributions of predisposing and situational risk factors serious fall injuries. $\mathrm{J}$ Am Geriatr Soc 43:1207-1213

129. Tinetti M, Speechley M (1989) Prevention of falls among elderly. N Engl J Med 320:1055-1059

130. Tinetti M, Speechley M, Ginter S (1988) Risk factor for falls among elderly living in the community. $\mathrm{N}$ Engl $\mathrm{J}$ Med 319:1701-1707

131. Vance DE, Ball KK, Roenker DL, Wadley VG, Edwards JD, Cissell GM (2006) Predictors of falling in older Maryland drivers: a structural-equation model. J Aging Phys Act 14:254 269

132. Weir E, Culmer L (2004) Fall prevention in the elderly population. Can Med Assoc J 171:724

133. Westerterp K, Meijer E (2001) Physical activity and parameters of aging: a physiological perspective. J Gerontol 56A:7-12

134. Woolf AD, Akesson K (2003) Preventing fractures in elderly people. BMJ 327:89-95

135. Woolley SM, Czaja SJ, Drury CG (1997) An assessment of falls in elderly men and women. J Gerontol A Biol Sci Med Sci 52: M80-M87

136. Yoshida K, Oida H, Kobayashi T, Maruyama T, Tanaka M, Katayama T, Yamaguchi K, Segi E, Tsuboyama T, Matsushita M, Ito K, Ito Y, Sugimoto Y, Ushikubi F, Ohuchida S, Kondo K, Nakamura T, Narumiya S (2002) Stimulation of bone formation and prevention of bone loss by prostaglandin E EP4 receptor activation. Proc Natl Acad Sci U S A 99:4580-4585

137. Zijlstra G, Haastregt J, Eijk J, Kempen G (2005) Evaluating an intervention to reduce fear of falling and associated activity restriction in elderly persons: design of a randomised controlled trial. BMC Public Health 5:1-9 